
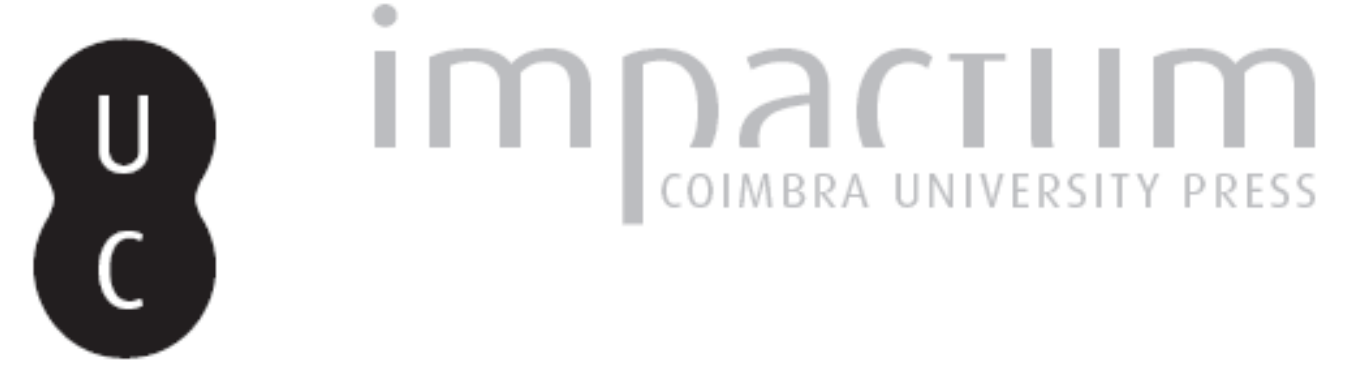

\title{
Was Waltho Van Claturbank's speech ever spoken? The fashion of London Quacks' speeches between the seventeenth and the eighteenth centuries
}

Autor(es): Mullini, Roberta

Publicado por: Faculdade de Letras da Universidade de Coimbra

URL persistente:

URI:http://hdl.handle.net/10316.2/32730

DOI:

DOI:http://dx.doi.org/10.14195/0870-4112_7_7

Accessed : $\quad$ 26-Apr-2023 13:53:05

A navegação consulta e descarregamento dos títulos inseridos nas Bibliotecas Digitais UC Digitalis, UC Pombalina e UC Impactum, pressupõem a aceitação plena e sem reservas dos Termos e Condições de Uso destas Bibliotecas Digitais, disponíveis em https://digitalis.uc.pt/pt-pt/termos.

Conforme exposto nos referidos Termos e Condições de Uso, o descarregamento de títulos de acesso restrito requer uma licença válida de autorização devendo o utilizador aceder ao(s) documento(s) a partir de um endereço de IP da instituição detentora da supramencionada licença.

Ao utilizador é apenas permitido o descarregamento para uso pessoal, pelo que o emprego do(s) título(s) descarregado(s) para outro fim, designadamente comercial, carece de autorização do respetivo autor ou editor da obra.

Na medida em que todas as obras da UC Digitalis se encontram protegidas pelo Código do Direito de Autor e Direitos Conexos e demais legislação aplicável, toda a cópia, parcial ou total, deste documento, nos casos em que é legalmente admitida, deverá conter ou fazer-se acompanhar por este aviso.

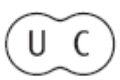




\section{Sociedade em Tumulto}

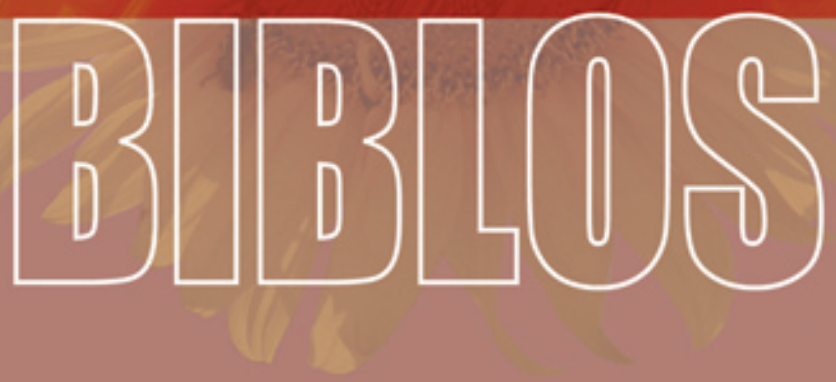

REVISTA DA FACULDADE DE LETRAS

UNIVERSIDADE DE GOIMBRA 
Biblos, n. s. VII (2009) 149-170

Roberta Mullini

University of Urbino "Carlo Bo", Italy

\section{WAS WALTHO VAN CLATURBANK'S SPEECH EVER SPOKEN? THE FASHION OF LONDON QUACKS' SPEECHES BETWEEN THE SEVENTEENTH AND THE EIGHTEENTH CENTURIES}

\section{Resumo}

Na segunda metade do século XVII, a vida social emLondres caracterizavase pela forte presença de charlatães que se tornaram, gradualmente, um verdadeiro fenómeno social. Este fenómeno foi frequentemente objecto dos ataques dos médicos do Royal College of Physicians e também da crítica de inúmeros escritores satíricos. O presente artigo estuda um discurso particular atribuído a um charlatão que se autodefine como "High German Doctor", conforme as várias aparições que fez e que estão documentadas em folhas estampadas e em muitas colectâneas de arengas de charlatães, à luz de uma fonte até agora ainda não identificada. Este discurso, paródia das palavras de um charlatão incluídas num panfleto satírico anónimo imprimido em 1676, é originariamente descrito como um exemplo do falar enganador dos charlatães. O facto de esta paródia ter sido reescrita e expandida no final do século XVII, e o facto de a nova versão ter sido muitas vezes reimpressa posteriormente e acompanhada de diferentes ilustrações, atesta que, não só a sociedade inglesa acolhia favoravelmente tais produtos satíricos, como também confirma a constante presença de charlatães no século XVIII.

Palavras-chave: charlatães, médicos, sátira.

\section{Abstract}

In the second half of the seventeenth century, irregular practitioners of medicine were a common feature of London life, and became a social phenomenon attacked not only by Royal College physicians, but also by satirists in their pamphlets. This article studies a particular speech attributed to a self-proclaimed "High German Doctor" which appeared in various and sundry broadsides and collections of quacks' harangues, in the light of an until now unacknowledged source. The latter, a parody of a quack's speech embedded in an anonymous satirical pamphlet printed in 1676, is originally presented as a 
specimen of quacks' deceitful discourse. The fact that this parody was rewritten and expanded towards the end of the century, and that the new version was later reprinted several times and with different illustrations, testifies not only to English society's favourable reception of this sort of satirical products, but also to the continuity of quacks' activities throughout the eighteenth century.

Keywords: practitioners of medicine, physicians, satire.

\section{A Labyrinth of Dates and Data}

If one looks up «Waltho van Claturbank» in the British Library Catalogue, one soon finds that it is the name of somebody who wrote (?) an eighteenth-century broadside entitled «Pharmacopola Circumforaneus, or the Horse Doctor's Harangue to the Credulous Mob», ${ }^{1}$ only that Claturbank is a pseudonym, and no real person seems to correspond to it. The first question arises, then, about the identity of this individual. Actually the name is mentioned for the first time as the speaker of a harangue with the above mentioned title in the collection Harangues or Speeches of Famous Mountebanks in Town and Country, a booklet of 64 pages plus a dedicatory letter assembled by an otherwise anonymous D.G., and printed in London at the beginning of the eighteenth century (its shelfmark in the British Library is 1038.g.46). In D.G.'s work, a possible date of which might be around 1700 but also 1725, the «Pharmacopola ...», occupies pages 13-19. The uncertainty about the publication date is analogous to everything concerning Waltho's speech and is the keynote of its subsequent editions. Indeed, almost certainly for its strong satirical content, this speech was often reproduced in broadsides (these, too, of uncertain date) and in the various reprints of D.G's collection.

The British Library also possesses another edition of the booklet (again with no date; shelfmark: 12330.k.121), which constitutes a totally peculiar object, it consisting of the original text interspersed with images and ephemera deriving from sundry sources. Most of the latter are quacks' handbills and newspaper cuttings advertising proprietary medicines, some are engravings of social scenes focusing on quacks' activity, some are broadsides. One of these is a two-column print entitled

${ }^{1}$ Christopher Merret, in The Accomplisht Physician, the Honest Apothecary, and the Skilful Chyrurgeon (London, s.n., 1670), translates «pharmacopola» into «seller of præpared Medicines» (p. 40). The whole phrase «pharmacopola circumforaneus» is used by Cicero for a charlatan selling medicines in a square. 
«Quack Doctor's Speech» (1760?), with no illustration, and reproduces Waltho Van Claturbank's words verbatim. ${ }^{2}$ D.G.'s work reappears anonymously in another version (shelfmark 11770.b.1(4)), bound with other items in a volume which starts with William Shakespeare's Julius Caesar. Here we find the date of print 1762 and a slightly different title: The Harangues or Speeches of several celebrated Quack-doctors, in Town and Country ... By various hands. This version, printed in a smaller typeface than the original, does not respect the page division of its 'forefather', and presents some changes (there are added «several merry receipts, and three mountebank songs»; the last speech in D.G. is omitted, while a new one is added at the beginning).

Besides the above mentioned broadside, though, Waltho's speech is also published in four other extant documents: one, printed in Dublin 1737?, is cited in the English Short-Title Catalogue (ESTC), with its «Pharmacopola Circumforaneus...» title and presents a three-column lettering; another, similar to the previous one but without title, belongs to the British Museum; ${ }^{3}$ a third is identical to the Dublin one, only that it is an engraving signed «T. Slater, sculp.» [London] (Fig. 1); the fourth simply entitled «The High German Doctor's Speech $»^{4}-$ is also datable around the $1730 \mathrm{~s} / 40 \mathrm{~s} ?,{ }^{5}$ printed for T. Kitchin, but there is no entry for it in the ESTC; its lettering is in two columns of elegant italics (Fig. 2).

Figure 1 represents «the doctor above named [Waltho] on horseback in a street, and attended by his zany; the former addresses a crowd of persons who are standing about him; some of them stretch forth their

${ }^{2}$ The edition accessible in the ECCO online collection (which I saw at the British Library) appears to be similar to D.G.'s version, but there are some images added (most of them present also in BL 12330.k.121), whereas the text starts only on p. 11, «The Infallible Mountebank, or Quack Doctor», therefore cutting the first pages which include a dedicatory letter and the first two speeches of the original edition.

${ }^{3}$ The Bodleian Library, Oxford, also has a copy of the speech, without any title (it is reproduced in M.A. Katritzy, 'Marketing Medicine: The Image of the Early Modern Mountebank', Renaissance Studies, 15: 2, 2001, 121-53, p. 139).

${ }^{4}$ This simplified title may cause some confusion because in D.G.'s collection there is another speech attributed to a German doctor («The High German Doctor and the English Fool», pp. 8-11), but the two texts are very different. In the second half of the seventeenth century many continental quacks promoted themselves by the appellation of «high German doctor».

5 For this date, see http://bp1.700.kcl.ac.uk/printsMonths/september 2008. htlm\#fn09 accessed 27/03/2009. 


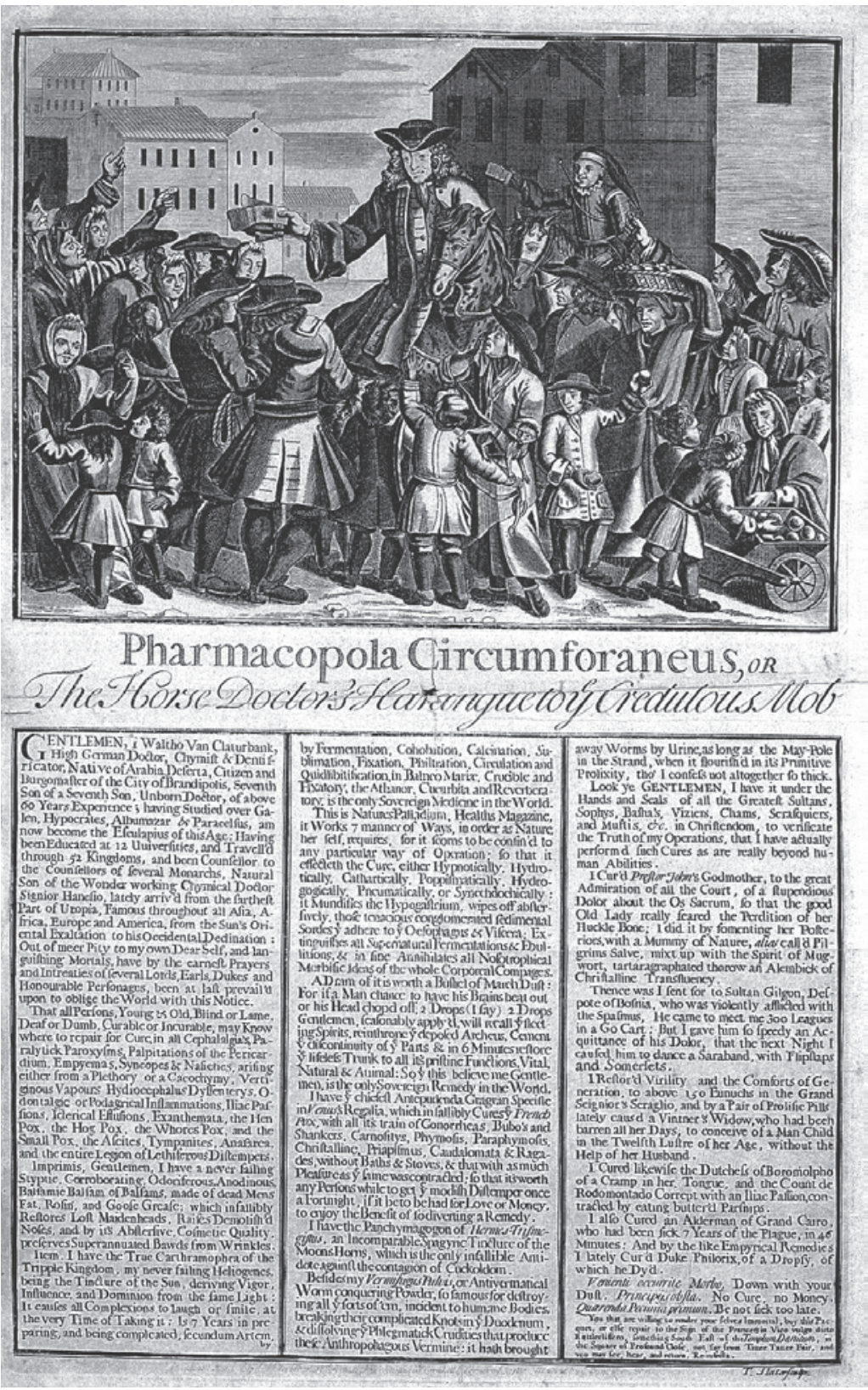

Fig. 1. A quack and his assistant arriving on horseback in a crowded town square. By courtesy of the Wellcome Library, London.

Faculdade de Letras | Universidade de Coimbra 
hands to receive papers which he is distributing. A boy with a monkey is in front; likewise a woman seated near a barrow full of fruit $»^{6}$, thus respecting the title-image correspondence. Figure 2 shows a mountebank on a stage, accompanied by two zanies, one of whom wears Harlequin's costume, while the other blows a trumpet. On the stage there is also another person, possibly a sick man, seated in an armchair, his right leg raised on a low stool. The mountebank holds a bottle (of medicine) in his left hand and is clearly addressing his audience, among which there are women, men and children.

Evidently, D.G.'s original collection of speeches was a great success: after what can be considered its first edition it was enriched with images, it was anthologized with other texts (no less than one of Shakespeare's plays!), and - given the existence of broadsides with passages from it - it helped popularize a literary sub-genre, i.e. that related to anti-quack satire, which throughout the seventeenth century had been dealt with especially by regular physicians' medical and polemical writings. ${ }^{7}$

\section{The Anti-Quack Medical Literature}

Even Desiderius Erasmus himself seems to have resorted to irregular physicians' medicines. In a letter dated 29 June 1517 the Venetian ambassador in London Sebastiano Giustinian wrote to him, who evidently had been ill, wishing «him better health than the quack medicines (pillula illa tua) given him by a foolish empiric can procure.» and trying to put him on his guard «against physicians, who

${ }^{6}$ Catalogue of Prints and Drawings in the British Museum Division I. Political and Personal Satires, (No. 1236 to No. 2015), Vol. II. June 1689 To 1733, Printed by order of the Trustees, 1873, no.1406, p. 152.

${ }^{7}$ In the last decades the research about British quackery has produced many relevant results; see in particular Roy Porter, Quacks. Fakers and Charlatans in English Medicine, Stroud, Tempus, 2000 and Idem, Bodies Politic. Disease, Death and Doctors in Britain 1650-1900, Ithaca - New York, Cornell University Press, 2001. For the relationships between the Royal College of Physicians, quacks and irregular practitioners, see Margaret Pelling, Medical Conflicts in Early Modern London: Patronage, Physicians, and Irregular Practitioners 1550-1640, Oxford, Clarendon Press, 2003. See also Andrew Wear, Health and Healing in Early Modern England, Aldershot, Ashgate, 1998, and M.A. Katritzky, Women, Medicine and Theatre, 1550-1750: Literary Mountebanks and Performing Quacks, Aldershot, Ashgate, 2007. 
make no difference in their treatment of horse and a man, and sometime use garlic for aloes (allium pro aloe).» ${ }^{8}$ Exactly the following year King Henry VIII founded the College of Physicians of London, which was to become the absolute - and powerful - arbiter of public medicine in the capital. But London citizens (and the British in general) still used folk and popular medicine, also because of the high fees of official physicians, and because the Galenic medicine of the time was not so different from what a wise woman or a medicine vendor could offer. The power of the College flexed its muscles against mountebanks and quacks from its beginning, attacking these irregular practitioners both on professional and on moral bases. Suffice it to quote from Johann Oberndorff's The Anatomyes of the True Physition, and Counterfeit Mounte-banke, translated into English in 1602. After presenting the 'character of a true doctor', the author describes the «Manners and Conditions» of medicine sellers:

For if a Man consider his [a quack's] Person, he shall finde him Lewd, Shamelesse, a Hater mortall of all Good Men, well seene and practiced in all Couzening, Legerdemaine, Coney-catching, and all other cunning Shifts, \& Sleights, a cracking Boaster, Proud, Insolent, a secret Back-biter, a contentious Wrangler, a common Iester, a Lyar, a Busie-body, a Runnagate Wanderer, a Cogging Sycophant, and Trencher-Chaplaine, a covetous Exactor, and Wringer of his Patients: in a word, a Man, or rather Monster, made of a Mixture of all Vices. ${ }^{9}$

Some years later, the «Doctor in Physicke» John Cotta, who wrote in English «for facilitie of common reading», reiterated the condemnation of quack activities. These people, «vile» and «unskilfull»,

${ }^{8}$ In Letters and Papers, Foreign and Domestic, of the Reign of Henry VIII. J. S. Brewer, ed. Vol. 2: Part II: 1517-18. London: Longman, Green, Longman \& Roberts, 1864, n. 3414.

9 Johann Oberndorf, The Anatomyes of the True Physition, and Counterfeit Mounte-banke, London, Printed for Arthur Iohnson, 1602, pp. 10-11. In his A Detection and Querimonie of the Daily Enormities and Abuses Co[m]mitted in Physick..., Londini, In aedibus Thomae Marshi, 1566, the physician John Securis had already censured «these sort [sic] of fellows which now a days almost in al places so rashly, so fondly and so wickedly do abuse the noble art and science of Phisicke», especially on a cultural basis, accusing them of lacking the necessary «knowledge of the tongues, of the liberall sciences, of Philosophie, of anatomie, of the simples, of the compound medicines, and of the temperatures of complexions» (sig. Avii, r).

Faculdade de Letras | Universidade de Coimbra 
Was Waltho Van Claturbank's Speech Ever Spoken?

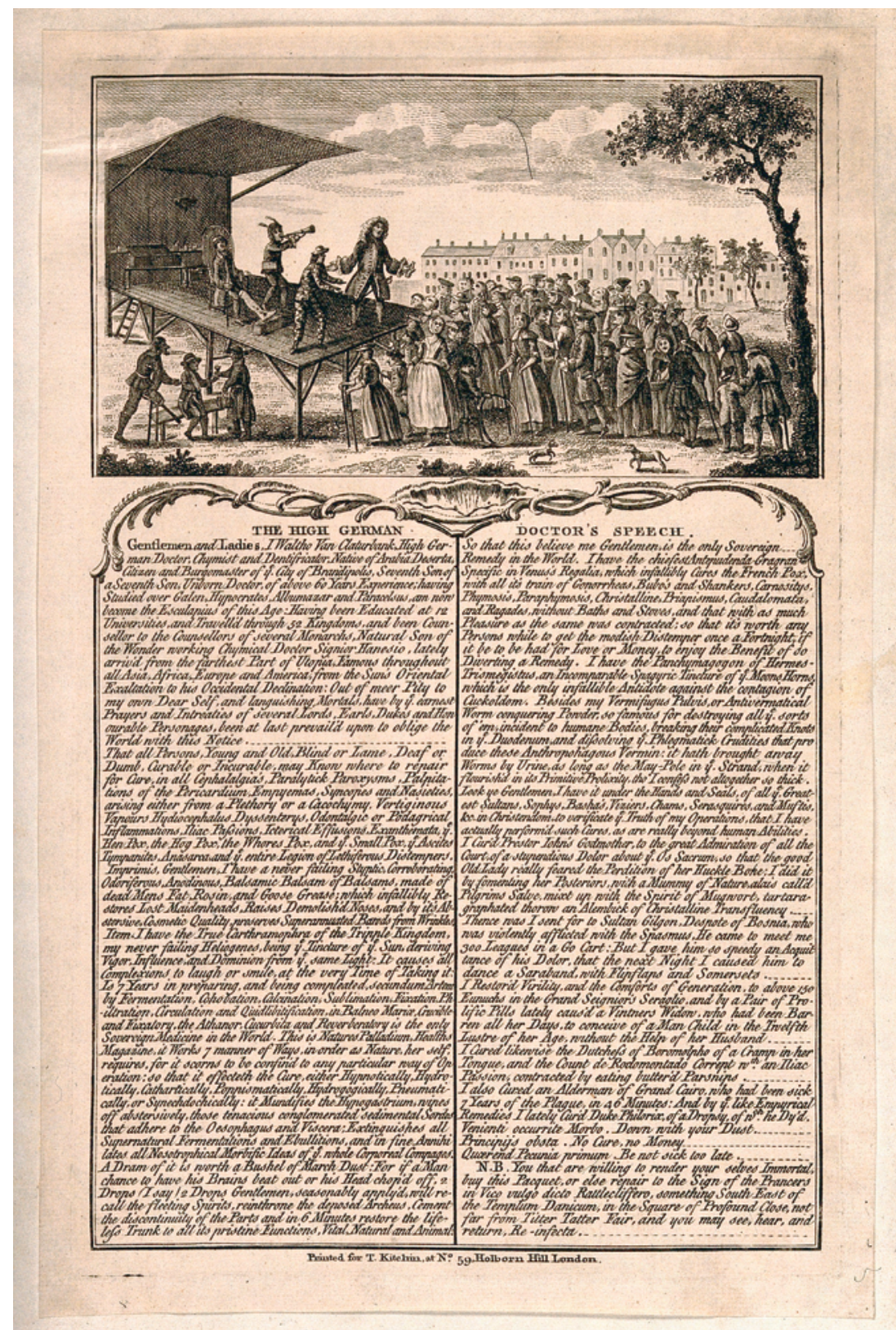

Fig. 2. A Dutch quack doctor promoting his wares before an audience. By courtesy of the Wellcome Library, London.

Faculdade de Letras | Universidade de Coimbra 
Without restraint, make gainefull traffique by botching in physicke; and hereby (besides many wicked practises, juglings, cousinages \& impostures, which maske unespied under the colour and pretence of medicining) numbers of unwotting innocents daily inthrall, and betray themselves, their lives and safetie, to sustaine the riot, lusts and lawlesse living of their enemies \& common homicides. ${ }^{10}$

This type of attacks is a common and never relenting feature during the whole seventeenth century, accompanied by satires of the quack as a public figure, the character of Scoto of Mantua in Ben Jonson's Volpone being the most famous fictional one (1606). Moral and professional condemnation of quackery continued to be published by physicians, but assaults became more and more satiric and the characters of mountebanks came to be the object of virulent descriptions based on social rather than medical grounds. Probably it was the wide spread of quackery in London, especially in the second half of the seventeenth century and after the plague in 1665, that favoured the production (and, evidently, the favourable reception) of pamphlets against mountebanks and empirics. These latter terms, in the meantime, had been more and more often supplanted by the word "quack", used generally to mean somebody who pretended a profession without being qualified for it, but in a more precise sense applied to false physicians or to practitioners who had not obtained a regular licence from the College of Physicians. ${ }^{11}$

Among the extant pamphlets containing the term "mountebank" or "quack" in their titles, some of which are political satires or parodies of the real quacks' books of cures, ${ }^{12}$ there is the anonymous The Character

${ }^{10}$ John Cotta, A True Discouery of the Empericke with the Fugitiue, Physition and Quacksaluer, London, William Iones, 1617, sig. A3v and p. 8.

${ }^{11}$ See Margaret Pelling, op. cit., for the differences (and conflicts) among London practitioners (especially ch. 5).

12 The anonymous The French Mountebank, or An Operator Fit for these Present Times (London, R. Austin and A. Coe, 1643) uses the now common frame of a mountebank's speech in order to conceal a political satire when offering a «Cordiall for this languishing Kingdome» and proclaiming the effects of his medicine against the «Caterpillars of the Common-wealth» (sig. Aiv, r). On the contrary, John Marriott's The English Mountebank: or, a Physical Dispensatory, wherein is Prescribed, Many Strange and Excellent Receits of Mr Marriot (London, George Horton, 1652) is a parody of charlatans' books of cures, containing improbable "receipts" (in this way quacks named their directions for the preparation of do-it-yourself medicines). 
of a Quack-doctor, or, The Abusive Practices of Impudent Illiterate Pretenders to Physick Exposed ${ }^{13}$ which mixes both a physician's reprimand against mountebanks and a more generally satiric look. It, consisting of only six tightly printed pages, first portrays - as the title announces - «the character of a quack-doctor» beginning from the definition of the term ( $« A$ Quack-Doctor is one of the Epidemical Diseases of this Age», p. 1), then goes on describing a quack's behaviour. It is exactly at this point, when the anonymous writer's voice deals with empirics' handbills, that - at last - a possible origin of Waltho's harangue can be found.

\section{The parody of quacks' handbills}

After writing about the «Angling Baits» of empirics, i.e. their use of boasts in extolling their nostrums especially when on a stage, the author of The Character... observes that the real «Draw-Net» is «a Printed Bill», which serves the false doctor to catch the fish «in shoals». The fishing metaphor is very fit to describe the quacks' habit of distributing handbills (and broadsides in the most elegant cases) to advertise their stuff, the medical marketplace being actually among the first instances of a prosperous advertising system in English society. ${ }^{14}$ The author, doubting the literacy of quacks, suggests that

he [the quack] ingages some Friend that's Book-Learn'd to correct the false English [...] and interlard it with Proverbial Lattin and Crampwords $[\ldots]$ then to a confiding printer he goes [...] and then out comes a Proclamation of wonders, trickt up in some strange form, with abundance of Inviting Capitals and Inticing Rubricks, the Tenour commonly to this effect $[\ldots]$ (p. 3)

${ }^{13}$ London, Printed for Thomas Jones, 1676.

${ }^{14}$ See T.R. Nevett, Advertising in Britain. A History, London, Heinemann, 1982; Elizabeth Lane Furdell, Publishing and Medicine in Early Modern London, Rochester, N.Y., University of Rochester Press, 2002; Louise Curth, 'Medical Advertising in the Popular Press: Almanacs and the Growth of Propriety Medicines', in Idem (ed.), From Physick to Pharmacology: Five Hundred Years of British Drug Retailing, Aldershot, Ashgate , 2006, pp. 29-47. 
thus also revealing his attention for the design of handbills and their paratextual apparatus. ${ }^{15}$

The pamphlet continues with a long, articulated and high-flown passage, written in the third person singular throughout four paragraphs (as if the quack were presenting himself Caesar-like), and in the first person singular in four others. What is transcribed in the Appendix at the end of this article is Waltho's speech from D.G.'s 'anthology', which has been compared with the anonymous parodic bill in The Character... The two texts match almost completely. This correspondence has never been noticed by critics, neither have bibliographers traced it when trying to date the broadside and D.G.'s anthology of harangues. It is possible to say, then, that Waltho's future speech has more than a simple 'analogue' as early as 1676, and that - while it figures as a direct address, spoken by the «Horse doctor» to a «credulous mob», i.e. oral discourse targeted on a gathering of people - it had been originally invented as a parody of those handbills that quacks handed out at fairs and along London streets.

The lettering of D.G.'s text, and that of the broadsides even more, uses capitals much more often than its direct source: the «inviting capitals» seem to have undergone, in the rewriting, a process of purposely burlesque inflation. The puffing and bombastic language is the same in the two documents; a lot of far-fetched and sometimes totally invented medical terms occur in both, building up series of alliterative and/or rhyming words in a grotesquely exaggerated accumulation; the satiric attitude is parallel, and the patients 'cured' by the two speakers/writers correspond. Some phrases are placed in a different sequence, but this does not alter the whole; there are, though, some changes worthwhile mentioning. The most relevant one, in my opinion, is the inversion of one of the proverbs at the end of the texts: the pamphlet reads «No Mony, no Cure», whereas the «Pharmacopola...» speech has «No Cure, No Money». It is not just an inversion of arithmetical addenda, since the meaning changes radically. The former phrase, actually, underlines the quacks' covetousness (= they are ready to cure only if previously paid); the latter, on the contrary, means that the irregular practitioner

${ }^{15}$ I have dealt with quacks' handbills in "With such flourishes as these": The Visual Politics of Charlatans' Handbills in Early Modern London', Textus. English Studies in Italy, 2009, 3 (forthcoming). 
requests to be paid only after the patient's recovery. ${ }^{16}$ In other words, the pamphlet is bitterer against quacks than D.G.'s collection and its derivative broadsides, which simply use a formula widely employed by real quacks in many still existing handbills in order to proclaim their honesty. One of the sayings cited in both works, though, is the Latin «Quærenda pecunia primum» which rather signifies avidity than generosity, thus letting readers glimpse the original meaning under the new word order.

Another significant change occurs in the adjective used for bawds in paragraph 3: The Character... calls them «super-animated» while they are «superannuated» in the «Pharmacopola...». The former adjective, not without a poignant sense in itself referring to the busy activity of bawds, might be a printer's mistake; the latter undoubtedly attacks the vanity of old ladies, who try to mask their age. ${ }^{17}$

\section{The "Haines case"}

The incipits of the two texts widely differ from each other in the quack's presentation. The parodic handbill invented in 1676, after printing the address of this fantastic doctor, says that he is «the Paracelsus of this age, by name Seignior Doloso Effrontero, Native of Arabia Deserta, natural Son of the wonder-working Chimest Doctor lately deceased at the Devils Arse [...]» (p. 3). The name, clearly reminding the reader of the negative meaning of both its parts, recalls those of Italian irregular practitioners, so frequent in seventeenth-century London, especially during the reign of Charles II. In D.G.'s Harangues... and in the

${ }^{16}$ This seems to correspond to the Italian "patto di guarigione"; see Gianna Pomata, Il patto di guarigione, Bari, Laterza, 1994 (Contracting a Cure: Patients, Healers, and the Law in Early Modern Bologna, Baltimore and London: Johns Hopkins University Press, 1998).

${ }^{17}$ It is worthwhile noticing that while the source and the broadside use the phrase «modish Distemper» as a synonym of the French Pox, the adjective has disappeared from D.G.'s text (and therefore is not reproduced in the Appendix). Was syphilis less fashionable at the beginning of the eighteenth century than before and afterwards? It does not seem so, at least according to the number of surviving handbills, the majority of which advertises cures against this disease (see K.P. Siena, 'The "Foul Disease" and Privacy: The Effects of Venereal Disease and Patient Demand on the Medical Marketplace in Early Modern London', Bulletin of the History of Medicine, 75, 2001, pp. 199-224, p. 204). 
«Pharmacopola...» broadsides deriving from it, on the contrary, not only is the name definitively Dutch and fictitious, but it is also accompanied by many different details and, especially, by the name of a real person:

Gentlemen, I Waltho van Claturbank, High German Doctor, Chymist, and Dentifricator, Native of Arabia Deserta, Citizen and Burgomaster of the City of Brandipolis, Seventh Son of a Seventh Son, Unborn Doctor of above 60 Years Experience, having studied over Galen, Hypocrates, Albumazar, and Paracelsus, am now become the Æsculapius of this Age. Having been educated at twelve Universities, and travelled through Fifty two Kingdoms, and been Counsellor to the Counsellors of several Monarchs, Natural Son of the Wonder-working Chymical Doctor Signior HANESIO, lately arrived from the farthest Parts of Utopia [...] (D.G., 13; my capitals)

Very probably the 'old' version from The Character... was adapted to the new historical situation which, after the Glorious Revolution in 1688 with a Dutch king now on the English throne, saw a lot of Dutch physicians arriving from the Continent. Not only that; Waltho uses all the formulaic paraphernalia of previous and contemporary quackery in proclaiming himself «Seventh Son of a Seventh Son, Unborn Doctor», thus attributing special occult medical powers to his own person..$^{18} \mathrm{He}$ also declares to be «Citizen and Burgomaster of the City of Brandipolis» and son of «Doctor Hanesio». It is these two very names - Brandipolis and Hanesio - which have prompted some critics to call this text «Joe Haines's Speech», connecting it to the Restoration comic actor Joseph Haines (or Haynes), whose name is Italianized as «Hanesio». ${ }^{19}$

Joe Haines, who was praised by Samuel Pepys as early as 1668 ( $7^{\text {th }}$ May) as an «incomparable dancer of the King's House [Theatre Royal, Drury Lane] and a seeming civil man» and a good singer, died in April 1701. In 1702 the satirist Thomas Brown published his Letters from the Dead to the Living, reprinted the following year and, later on,

${ }^{18}$ See C.J.S. Thompson, The Quacks of Old London, New York, Barnes and Noble, 1993 (1928), p. 188.

${ }^{19}$ One of these is Robert Chambers, who plainly declares that «his [Haines's] burlesque speech was published as a broadside with an engraving representing his temporary stage" (The Book of Days, Edinburgh, W. \& R. Chambers, 1864, 2 vols, vol. 1, p. 512). The engraving, printed on the same page, comes from the here reproduced Fig. 2, though, not from Fig. 1.

Faculdade de Letras | Universidade de Coimbra 
as part of Brown's Works ${ }^{20}$ in which one of the correspondents from the nether world is Joe Haines. Haines-the character finds himself in Pluto's capital city, Brandipolis, where he hires a house and sets up as physician and fortune-teller under the name of Giuseppe Hanesio. Therefore the connection between Haines, Brandipolis and medical activities is in a way settled by Brown's work not earlier than 1702, above all because of the proclamation of Hanesio as «Signior Giusippe Hanesio, High German Astrologer and Chymist, Seventh Son of a Seventh Son, Unborn Doctor, of above Sixty Years Experience, Educated in Twelve Universities, having Travell'd through Fifty-two Kingdoms, and been Counsellor of several Monarchs», ${ }^{21}$ a long sentence that re-occurs at the beginning of the «Pharmacopola...» nearly verbatim. According to one of his biographers, at a certain time of his life - even if no date is given for these events - Haines «determined to turn mountebank, and set out with a retinue of tumblers, dancers, \&c. for Hertford», where "great was his practice, and great his applause; the invalids and curious of all ages flocking to him. ${ }^{22}$ Besides his theatrical activity, then, Haines appears to have tried a quack's life, and Thomas Brown to have linked the actor's real identity to his own fiction.

The attribution of the paternity of Waltho's speech to Haines, so, would seem quite plausible, only that D.G.'s original anthology contains another harangue specifically named «Joseph Haines's Speech, HighGerman Doctor and Astrologer in Brandipolis», different from the «Pharmacopola...», in spite of some common passages. Furthermore there also exists an image entitled «Joe Haynes's Mountebank's Speech», which differs from those recalled so far (Fig. 3). ${ }^{23}$ The above

${ }^{20}$ «Brown's choice of his correspondent, the recently deceased "Joseph Haines of Merry Memory", was both literally apt and commercially shrewd, designed to attract the attention of fashionable readers» (David Mazella, 'Diogenes the Critic in the Dialogues of the Dead of Thomas Brown, Lord Lyttleton, and William Blake', Texas Studies in Literature and Language, vol. 48, n. 2, Summer 2006, pp. 102-122.

${ }^{21}$ Thomas Brown's Letters, cit., p. 12 (1707 edn.). The Catalogue of Prints and Drawings in the British Museum (cit., p. 152) asserts that «The text [of the broadside] appears to be a parody» of the proclamation itself.

22 John Galt, The Lives of the Players, 2 vols., London, Henry Colburn and Richard Bentley, 1831; vol. 1, p. 38.

${ }^{23}$ D.G., op. cit., pp. 35-43. The image is in the copy shelfmarked BL 12330.k.121 and in the ECCO collection, but not in the one shelfmarked BL 1038.g.46. The engraving derives from the second volume of Thomas Brown's Works, 1719, p. 167 
mentioned passage from Thomas Brown, as can be seen by comparing it with the incipit in the Appendix, coincides with what most diversifies «Pharmacopola...» from The Character.... Other portions of Haines's speech seem to have migrated to Waltho's text, especially to the latter's paragraphs 4, 5, 7 and 9. These are exactly the parts shared by Haines's and Waltho's speeches in a relation of reciprocal dependence. D. G., then, has integrated The Character... with passages 'usable' on various occasions. While paragraphs 4, 7 and 9 simply mirror (or are mirrored by) passages from Haines's harangue, in paragraph 5 D.G. shows his special jocular vein. The two speeches, actually, share almost the whole paragraph, diverging only for the funny series of alliterative and rhyming adverbs. These are juxtaposed in a breath-taking list by Waltho: «Hypnotically, Hydrotically, Cathartically, Poppismatically, Hydrogogically, Pneumatically, or Synechdochically» (D.G., p. 15), and 'explained' by Haines as follows, in order to specify the multiple actions of his medicine, which works

Hypnotically, by throwing the Party into a gentle Slumber, Hydrotically; by their Operative Faculty, in opening the Interstitia Pororum, Cathartically, by cleansing the Bowels of all Crudities and tartarous Mucilage, with which they abound; Proppismatically, by forcing the Wind downward; Hydrogogically, by exciting Urine; Pneumatically, by exhilarating the Spirits; and lastly, or Synecdochically, by corroborating the whole Oeconomia Animalis. (D.G., p. 37; my small capitals)

From the comparison of these two textual portions, the mirroring/ sharing process emerges in a clear manner: when writing «Joe Haines's Speech» and «Pharmacopola...» D.G. made use of interchangeable blocks of phrases, and, economizing on his own and his printer's time, he repeated them in both texts, thus adding to the original parodic bill from The Character....

The main question, though, remains: was Mr Haines's speech ever spoken? Or was Waltho van Claturbank's? And which is the source for the other? It is possible to hypothesize that the real Joseph Haines, when

(it is a variation of a slightly different previous image, 1691, reproduced in John H. McDowell, 'Some Pictorial Aspects of Early Mountebank Stages', PMLA, 61:1, Mar. 1946, 84-96, Figure 6).

Faculdade de Letras | Universidade de Coimbra 


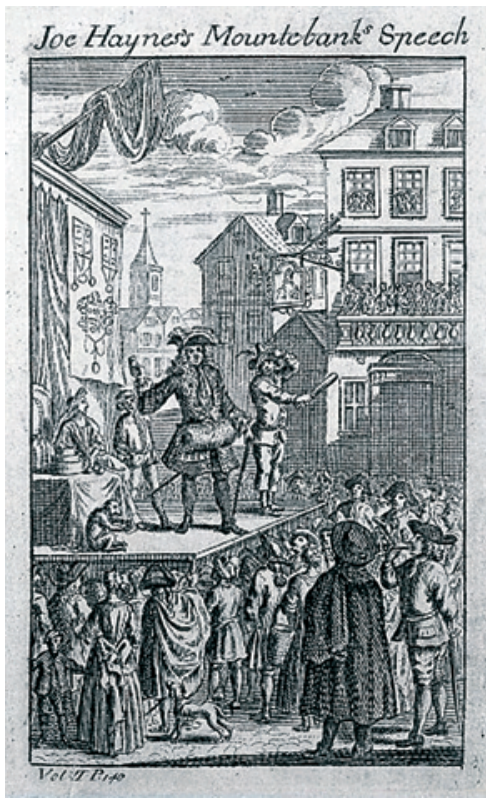

Fig. 3. Joe Haynes's Mountebank Speech. (An itinerant medicine vendor selling his wares from astage to a large audience in a town square. By courtesy of the Wellcome Library, London).

"playing the mountebank", made use of the parody of handbills from The Character... for his burlesque open-air speeches (or even for his theatrical ex tempore performances), inventing "Waltho van Claturbank" as one of his impersonations. D.G. - whoever he was - when compiling his little volume of Harangues or Speeches of famous Mountebanks may be supposed to have transcribed two satires of Haines's against quacks, one with the actor's name, the other with his alter ego's. Or another hypothesis can be made: D.G. capitalized on the success of Haines as an actor on one side, and on the fortune of Thomas Brown's Letters from the Dead with its Brandipolis on the other, so as to compile two appealing and partly coinciding speeches for readers à la mode, to be printed together with such famous pieces as Scoto of Mantua's harangue from Volpone, II.ii (the last piece in the collection). What is certain is that between the seventeenth and the eighteenth centuries a real fashion for non-medical parodies of quacks exploded, so that with or without images, these parodies were published (and pirated, I suppose) by many printers. The existence of at least five versions of Waltho's speech in broadside format testifies to a wide readership and to the posthumous fortune of what some anonymous satirist had written in the nearly forgotten source of all this, The Character of a Quack-Doctor, printed in 1676. 


\section{Appendix ${ }^{24}$}

«Pharmacopola Circumforaneus, or The Horse Doctor's Harangue to the Credulous Mob» (and its 'analogue' in The Character of a QuackDoctor)

1. Gentlemen, I Waltho van Claturbank, High German Doctor, Chymist, and Dentifricator, Native of Arabia Deserta, Citizen and Burgomaster of the City of Brandipolis, Seventh Son of a Seventh Son, Unborn Doctor of above 60 Years Experience, having studied over Galen, Hypocrates, Albumazar, and Paracelsus, am now become the Æsculapius of this Age. Having been educated at twelve Universities, and travelled through Fifty two Kingdoms, and been Counsellor to the Counsellors of several Monarchs, Natural Son of the Wonderworking Chymical Doctor Signior Hanesio, lately arrived from the farthest Parts of Utopia, Famous throughout Asia, Africa, Europe and America, from the Sun's Oriental Exaltation to his Occidental Declination: Out of dear Pitty to my own dear Self, and languishing Mortals, have by the earnest Prayers and Intreaties of several Lords, Earls, Dukes, and Honourable Personages, been at last prevail'd upon to oblige the World with this Notice.

2. That all Persons, Young and Old, Blind or Lame, Deaf or Dumb, Curable or Incurable, may know where to repair for Cure, in all Cephalalgia's, Paralytick Paroxysms, Palpitations of the Pericardium, Empyemas, Syncopes, and Nasieties, arising either froma Plethory or a Cachochymy, Vertiginous Vapours, Hydiocephalus Dissenteries, Odontalgick, or Podagrical Inflammations, Iliack Passions, Icterical Effusions, Exanthemata, the Hen pox, the Hog Pox, the Whores Pox, and the Small Pox, the Assites, Tympanites, Anasarca, and the entire Legion of Lethiferous Distempers.

${ }^{24}$ The text is copied from D.G.'s Harangues... (original italics are not reproduced) and checked with the 'Waltho' broadsides (which respect both the wording and the paragraphs' structure of the original). Paragraph numbers are mine. The following typefaces are used to highlight the parts to be found also in The Character of a QuackDoctor: boldface shows repetitions of exactly the same wording in the same position; italics are used for similar-cum changes wording; underlining signals the occurrence of identical portions of text, which are placed in a different position in the 'analogue' (spelling variations are not taken into consideration, while some variants occurring in The Character... are added between square brackets). 
3. Imprimis, Gentlemen, I have a never-failing Styptick, corroborating, odoriferous, anodinous, balsamic Balsam of Balsams, made of dead Mens Fat, Rosin, and Goose Grease, which infallibly restores lost Maidenheads, raises demoish'd Noses, and by its abstersive, cosmetick Quality, preserves superannuated Bawds from Wrinkles.

4. Item. I have the True Carthramophra of the Triple Kingdom, my never-failing Heliogenes, being the Tincture of the Sun, deriving Vigour, Influence, and Dominion from the same Light; it causes all Complexions to Laugh or Smile, at the very Time of taking it; is seven Years in preparing, and being compleated, secundum Artem // by Fermentation, Cohobation, Calcination, Sublimation, Fixation, Philtration, Circulation and Quidlibitification, in Balneo Mariæ, Crucible and Fixatory, the Athanor, Cucurbita and Reverberatory, is the only Sovereign Medicine in the World.

5. This is Natures Palladium, Health's Magazine; it works seven manner of Ways, in order as Nature herself requires, for it scorns to be confin'd to any particularway of Operation; so that it effecteth the Cure, either Hypnotically, Hydrotically, Cathartically, Poppismatically, Hydrogogically, Pneumatically, or Synechdochically; it mundifies the Hypogastrium, wipes off abstersively those tenacious conglomerated sedimental Sordes that adhere to the Oesophagus and Viscera; extinguishes all supernatural Fermentations and Ebulitions, and, in fine, annihilates all Nosotrophical Morbifick Ideas of the whole Corporeal Compages.

6. A Drachm of it is worth a Bushel of March Dust; for, if a Man chance to have his Brains beat out, or his Head chop'd off, 2 Drops, I say, 2 Drops Gentlemen, seasonably apply'd, will recall the fleeting Spirits, re-inthrone the deposed Archeus, cement the Discontinuity of the Parts, and in six Minutes restore the lifeless Trunk to all its pristine Functions, Vital, Natural, and Animal; so that this, believe me, Gentlemen, is the only Sovereign Remedy in the World.

7. I have the chiefest Antepudenda Gragran Specifick in Venus Regalia, which infallibly cures the French Pox, with all its Train of Gonorrheas, Bubo's and Shankers, Carnosities, Phymosis, Paraphymosis, Christalline Priapismus, Caudalomata and Ragades, without Baths and Stoves, and that with as much Pleasure as the same was contracted; so that 'tis worth any Person's while to get the Distemper once a Fortnight, if it be to be had for Love or Money, to enjoy the Benefit of so diverting a Remedy. 
8. I have the Panchymagogon of Hermes Trismegistus, an incomparable Spagyric Tincture of the Moons Horns, which is the only infallible Antidote against the Contagion of Cuckoldom.

9. Besides, my Vermifugus Pulvis, or Antivermatical Worm-conquering Powder, so famous for destroying all the Sorts of 'em, incident to human Bodies, breaking their complicated Knots in the Duodenum, and dissolving the Phlegmatick Crudities that produce these Anthropohagous Vermine: It hath brought away Worms by Urine, as long as the May-Pole in the Strand, when it flouresh'd in its Primative Prolixity, tho' I confess not altogether so thick.

10.Look ye Gentlemen, I have it under the Hands and Seals of all the Greatest Sultans [Caliphs], Sophys, Bashas, Viziers, Chams, Serasquiers, and Mufties, \&c. in Christendom, to verificate the Truth of my Operations, that I have actually performed such Cures as are really beyond human Abilities.

11. I cur'd Prestor John's Godmother, to the great Admiration of all the Court, of a stupendious Dolour about the Os Sacrum, so that the good old Lady really feared the Perdition of her Huckle-Bone; I did it by fomenting her Posteriors, with a Mummy of Nature, alias, called Pilgrim'sSalve, mix'd up with theSpirit of Mugwort, tartaragraphated thorough an Alembick of Christalline Transfluency.

12. Thence was I sent for to Sultan Gilgon. Despote of Bosnia, who was violently afflicted with the Spasmus: He came to meet me 300 Leagues in a Go Cart: But I gave him so speedy an Acquittance of his Dolour, that the next Night I caused him to dance a Saraband, with Flipflaps and Somersets.

13.I restor'd Virility, and the Comforts of Generation, to above 150 Eunuchs in the Grand Senior's Seraglio, and by a Pair of Prolifick Pills, lately caused a Vintner's Widow, who had been barren all her Days, to conceive of a Man Child [all her life time, to bring forth a lusty boy] in the twelfth Lustre of her Age, without the Help of her Husband.

14.I cured likewise the Dutchess of Boromolpho [Promolpho] of a Cramp in her Tongue, and the Count de Rodomontado Corrept with an Illiack Passion, contracted by eating butter'd Parsnips.

15.I also cured an Alderman of Grand Cairo, who had been sick seven Years of the Plague, in 46 Minutes: And by the like Empirical Remedies I lately cured Duke Philorix, of a Dropsy, of which he died. 
16. Venienti occurite morbo. Down with your Dust. Principiis obsta. No Cure, no Money [No mony, no Cure]. Quarenda Pecunia primum. Be not sick too late.

17. You that are willing to render yourselves Immortal, buy this Packet, or else repair to the Sign of the Prancers in Vico vulgo dicto Rattlecliffero, something South-East of the Teplum Danicum, in the Square of Profound-Close, not far from Titter-Tatter Fair, and you may see, hear, and return Reinfecta.

\section{Primary sources}

Anon., The High German Doctor's Speech, London, 1730s/40s?, printed for T. Kitchin.

Anon., Gentlemen, I Waltho Van Claturbank..., London, printed for John Bowles, 1700?, (seen at http://www.britishmuseum.org/research/ search_the_collection_database accessed 28/03/09).

Anon., Pharmacopola Circumforaneus, or the Horse Doctor's Harangue to the Credulous Mob, London, T. Slater, sculp., 17th century?

Anon., Pharmacopola Circumforaneus, or the Horse Doctor's Harangue to the Credulous Mob, Dublin, 1737?

Anon., Quack Doctor's Speech, 1760? (in D. G. Harangues or Speeches of Famous Mountebanks in Town and Country, London, s.n., 1725?, British Library shelfmark 12330.k.121).

Anon., The Character of a Quack-doctor, or, The Abusive Practices of impudent illiterate Pretenders to Physick exposed, London, Printed for Thomas Jones, 1676.

Anon., The French Mountebank, or An Operator Fit for these Present Times, London, R. Austin and A. Coe, 1643

Anon., The Harangues or Speeches of several celebrated Quackdoctors, in Town and Country ... By various hands, London, J. Thomson, 1762 (British Library shelfmark 11770.b.1(4)).

Cotta, John, A True Discouery of the Empericke with the Fugitiue, Physition and Quacksaluer, London, William Iones, 1617.

G., D., Harangues or Speeches of Famous Mountebanks in Town and Country, London, Printed for T. Warner, at the Black-Boy, in PaterNoster-Row, 1700? (British Library shelfmark 1038.g.46).

G., D., Harangues or Speeches of Famous Mountebanks in Town and Country, London, s.n., 1725? (British Library shelfmark 12330.k.121). 
Marriott, John, The English Mountebank: or, a Physical Dispensatory, wherein is Prescribed, Many Strange and Excellent Receits of Mr Marriot (London, George Horton, 1652.

Merret, Christopher, The Accomplisht Physician, the Honest Apothecary, and the Skilful Chyrurgeon, London, s.n., 1670.

Oberndorf, Johann, The Anatomyes of the True Physition, and Counterfeit Mounte-banke, London, Printed for Arthur Iohnson, 1602.

Securis, John, A Detection and Querimonie of the Daily Enormities and Abuses Co[m]mitted in Physick..., Londini, In aedibus Thomae Marshi, 1566.

\section{Secondary sources}

Chambers, Robert, The Book of Days, 2 vols, Edinburgh, W. \& R. Chambers, 1864.

Curth, Louise, 'Medical Advertising in the Popular Press: Almanacs and the Growth of Propriety Medicines', in Idem (ed.), From Physick to Pharmacology: Five Hundred Years of British Drug Retailing, Aldershot, Ashgate , 2006, 29-47.

Furdell, Elizabeth Lane, Publishing and Medicine in Early Modern London, Rochester, N.Y., University of Rochester Press, 2002.

Katritzky, M.A., Women, Medicine and Theatre, 1550-1750: Literary Mountebanks and Performing Quacks, Aldershot, Ashgate, 2007.

Katritzy, M.A., 'Marketing Medicine: The Image of the Early Modern Mountebank', Renaissance Studies, 15: 2, 2001, 121-53.

Letters and Papers, Foreign and Domestic, of the Reign of Henry VIII. J. S. Brewer, ed. Vol. 2: Part II: 1517-18. London: Longman, Green, Longman \& Roberts, 1864.

Mullini, R., "With such flourishes as these": The Visual Politics of Charlatans' Handbills in Early Modern London', Textus. English Studies in Italy, 2009, 3 (forthcoming).

Nevett, T.R., Advertising in Britain. A History, London, Heinemann, 1982.

Pelling, Margaret, Medical Conflicts in Early Modern London: Patronage, Physicians, and Irregular Practitioners 1550-1640, Oxford, Clarendon Press, 2003.

Pomata, Gianna, Il patto di guarigione, Bari, Laterza, 1994 (Contracting a Cure: Patients, Healers, and the Law in Early Modern Bologna, Baltimore and London: Johns Hopkins Unuversity Press, 1998).

Faculdade de Letras | Universidade de Coimbra 
Porter, Roy, Bodies Politic. Disease, Death and Doctors in Britain 1650-1900, Ithaca - New York, Cornell University Press, 2001.

Porter, Roy, Quacks. Fakers and Charlatans in English Medicine, Stroud, Tempus, 2000.

Siena, K.P., "The "Foul Disease" and Privacy: The Effects of Venereal Disease and Patient Demand on the Medical Marketplace in Early Modern London', Bulletin of the History of Medicine, 75, 2001, 199-224.

Stephens, F. G. (ed.), Catalogue of Prints and Drawings in the British Museum Division I. Political and Personal Satires, (No. 1236 to No. 2015), Vol. II. June 1689 To 1733, London, Printed by order of the Trustees, 1873.

Thompson, C.J.S., The Quacks of Old London, New York, Barnes and Noble, 1993 (1928).

Wear, Andrew, Health and Healing in Early Modern England, Aldershot, Ashgate, 1998. 